Original Article

\title{
Accuracy of Preoperative Computed Tomography for Lymph Node Status Screening in Colon Cancer
}

\section{Kolon Kanseri Hastalarında Lenf Nodu Durumunu Görüntülemede Preoperatif Bilgisayarlı Tomografinin Doğruluğu}

\author{
Mustafa Taner Bostanc1 ${ }^{1}$, İbrahim Y1lmaz ${ }^{1}$, Yeliz Aktürk², Aysun Gökçe ${ }^{3}$, \\ Mehmet Saydam ${ }^{1}$, Işı1 Esen Bostanc1 ${ }^{4}$
}

${ }^{1}$ University of Health Sciences, Dışkap1 Yıldırım Beyazıt Training and Research Hospital, Department of General Surgery, Ankara

${ }^{2}$ University of Health Sciences, Dışkapı Yıldırım Beyazıt Training and Research Hospital, Department of Radiology, Ankara

${ }^{3}$ University of Health Sciences, Dışkapı Yıldırım Beyazıt Training and Research Hospital, Department of Pathology, Ankara

${ }^{4}$ University of Health Sciences, Dr Abdurrahman Yurtaslan Oncology Training and Research Hospital, Department of Radiology, Ankara

\begin{abstract}
Introduction: Our aim is to determine the value of a pre-operative Computed Tomography (CT) scan for the assessment of lymph node status in patients diagnosed with colon cancer by comparing between radiological $\mathrm{N}$-stage and histopathological $\mathrm{N}$-stage.

Methods: After approving by local ethics committee, an experinced radiologist reviewed all preoperative CT scans of patients diagnosed with colon cancer retrospectively, between January 2014 and December 2018. The CT scans were examined for any signs of regional lymphatic spread which was defined as lymph nodes exceeding $1 \mathrm{~cm}$, clusters of $\geq 3$ lymph nodes or a combination of the two. The results were compared with the histopathological $\mathrm{N}$-stage. The diffrences in comparison were eveluated statistically and positive predictive value (PPV), negative predictive value (NPV), sensitivity, specificity and accuracy were calculated.

Results: We included 184 patients in our study. The statistical values of PPV, NPV, sensitivity, specificity, and accuracy of detecting regional lymph nodes metastases were $65.6 \%, 75 \%, 58.3 \%, 80.3 \%$ and $71.7 \%$, respectively. The assessment of lymph node status with CT scans resulted in a moderate sensitivity, specificity and accuracy for both subgroups, defined as emergency and tumor localization subgroups.

Discussion and Conclusion: Although our study group is relatively large and homogeneous compared to previous studies, the obtained results in the evaluation of patients with colon cancer with preoperative CT does not seem to be satisfactory. Before making the treatment decisions according to the appearance of lymph nodes in colon cancer patients on CT images, the diagnostic accuracy needs strong improvement, such as thinner axial slices and three-dimensional reconstruction methods.
\end{abstract}

Keywords: Colon cancer, Lymph nodes status, Computed tomography, Preoperative staging

\section{ÖZET}

Giriş ve Amaç: Çalışmamızda kolon kanseri tanılı hastalarda radyolojik ve histopatolojik lenf nodu evresini kıyaslayarak preoperatif bilgisayarlı tomografi (BT) ile taramanın lenf nodu durumunu belirlemedeki değerini belirlemeyi amaçladık.

Yöntem ve Gereçler: Ocak 2014 ve Aralık 2018 tarihleri arasında kolon kanseri tanısı almış olan hastaların preoperatif BT taramaları alanında deneyimli bir radyolog tarafindan geriye dönük olarak 
incelendi. Görüntülerde bölgesel lenf nodu yayılımının göstergesi olarak $1 \mathrm{~cm}$ 'den büyük lenf nodu, $\geq 3$ kümelenmiş lenf nodları veya her ikisinin de mevcut olması kabul edilmiştir. Sonuçlar histopatolojik lenf nodu evresi ile kıyaslandı. Ardından, pozitif prediktif değer (PPD), negatif prediktif değer (NPD), sensitivite, spesifisite ve doğruluk değerleri hesapland.

Bulgular: Çalışmamıza 184 hasta dahil olmuştur. Bölgesel lenf nodu metastazının tespitinde tespit edilen PPD, NPD, sensitivite, spesifisite ve doğruluk değerleri sırasıyla $\% 65.6, \% 75, \% 58.3, \% 80.3$ ve \%71.7 idi. Acil ve tümör yerleşimi gibi alt gruplarda BT ile lenf nodunun değerlendirilmesinde ise BT'nin orta düzey sensitivite, spesifisite ve doğruluğa sahip olduğu görüldü.

Tartışma ve Sonuç: Çalışmamız daha önceden yapılmış olan çalışmalara göre nispeten daha çok hasta içermesi ve daha homojen yapıda olmasına rağmen, kolon kanseri hastalarının preoperatif BT ile lenf nodu durumunu değerlendirilmesinde tatmin edici sonuçlara ulaşılamamıştır. BT görüntülemedeki lenf nodunu görünümüne göre tedaviye yön vermede tanısal doğruluğu arttıracak ince aksiyal kesitler ve üçboyutlu rekonstruksiyon yöntemleri gibi güçlü gelişmelere gereksinim vardır.

Anahtar Kelimeler: Kolon kanseri, Lenf nodu durumu, Bilgisayarlı tomografi, Preoperatif evreleme

\section{Introduction}

Colorectal Cancer (CRC) is the most common diagnosed gastrointestinal neoplasm in western world. Approximately $70 \%$ of cases are located to colon and the treatment for resectable CRC is curative surgery with adequate lymph node (LN) dissection.

Preoperative chemoradiotherapy is the approved treatment to make smaller the tumor size and prevent local recurrences for highrisk rectum cancer [1]. American Joint Committee on Cancer (AJCC) recommends adjuvant chemotherapy for stage 3 colon cancer [2]. Colorectal surgeons have began to prefer neoadjuvant chemotherapy (NAC) for high-risk colon cancer preoperatively to prevent local recurrences after surgery; however, determining the appropriate patient for neoadjuvant therapy became more important [3]. Endorectal ultrasonography (EUS) and magnetic resonance imaging (MRI) are used to stage rectum cancer patients for NAC, but EUS is not appropriate for colon neoplasms, and also positron emission tomography (PET) and MRI have a low sensitivity $[4,5]$. Therefore, CT seems to be the only imaging modality to determine the distant metastasis and LN status and to select appropriately colon cancer patients for NAC. We aimed to reveal the effect of preoperative
CT in diagnosing the LN status in colon cancer.

\section{Material and Methods}

After the local ethics committee approval (25.12.2017-44/15), the hospital records of elective and emergency curative surgery performed patients between January 2014 and December 2018 were analyzed retropectively. Rectum neoplasms, NAC performed patients, synchronous neoplasms, stage 4 neoplasms, palliative surgery (bypass or enterostomy) performed patients, recurrent colon neoplasms, less than $12 \mathrm{LN}$ dissected patients and CT images missing patients were excluded from the study. CT images were examined by a single radiologist (YA) with more than 10 years of abdominal CT experience by knowing only the primary tumor localization of the patient. Radiological examination defined positive $\mathrm{LN}$ as; diameter $>1 \mathrm{~cm}$ regional $\mathrm{LN}$ andlor count of $\geq 3$ clustered regional LN. Intravenous (IV) and oral contrast agents were performed for all elective cases, and only IV contrast agent was performed for emergency cases.

The abdomen of the patients was scanned from diaphragm to pelvis with Toshiba Alexion 16 slice CT Scanner. Iohexol 300 mg $\mathrm{I} / \mathrm{mL}$ was administered intravenously according to the weight of the patient with an 


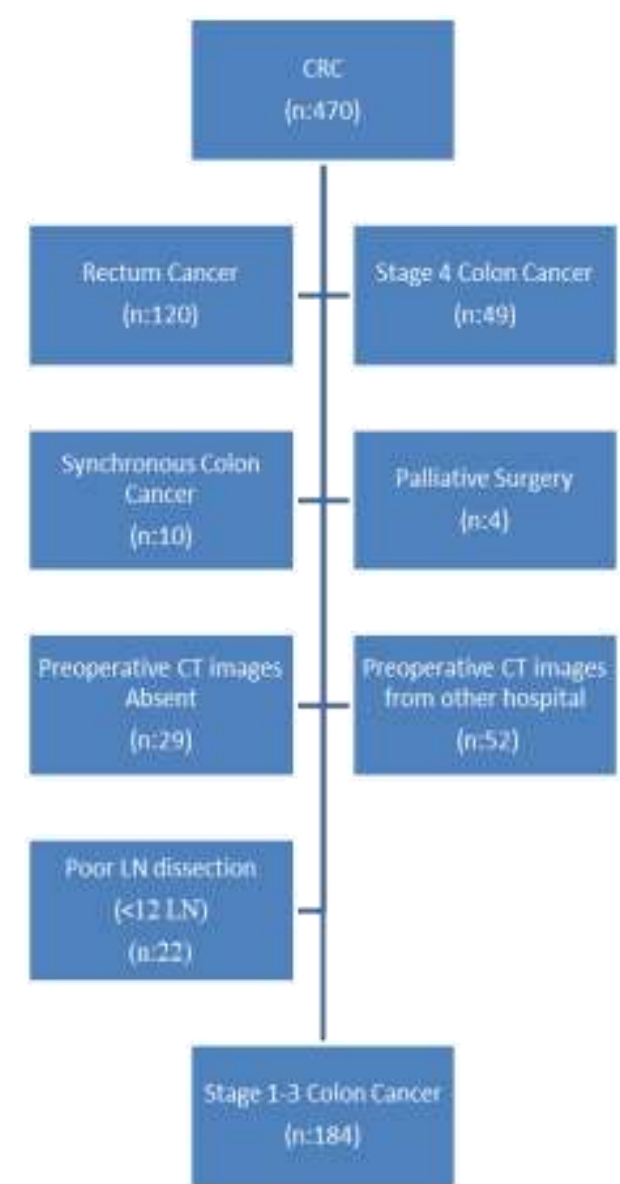

Figure 1. Inclusion and exclusion criteria

Imaxeon syringe. All CT scans were viewed on $3 \mathrm{~mm}$ axial sliced images. The maximum short axis in the axial plane was measured. All captured images were recorded in the hospital's PACS system.

Histopathological examinations of resected colon specimens were performed compatible with standard references, and LN were isolated by the only dissection, without oil cleaning techniques. The differentiation of $\mathrm{pN} 1$ and $\mathrm{pN} 2$ was made compatible with TNM classification, 8th edition, in subgroup analysis [6].

The data analyses were done with IBM SPSS Statistics 17.0 (IBM Corporation, Armonk, NY, USA) package software. Sensitivity, specificity, positive predictive value (PPV), negative predictive value (NPV) and accuracy of CT were analyzed.
Table 1. The patients and neoplasm demographics

\begin{tabular}{|c|c|}
\hline \multirow{2}{*}{$\begin{array}{l}\text { Stage 1-3 colon cancer } \\
\text { patients } \\
\text { Gender }\end{array}$} & $\mathrm{N}(\%)$ \\
\hline & 184 \\
\hline Male & $110(59.7)$ \\
\hline Female & $74(40.3)$ \\
\hline Age & 660 \\
\hline Range & $\begin{array}{c}\text { b6.0 } \\
38-91\end{array}$ \\
\hline Surgery & \\
\hline Emergency & $53(28.8)$ \\
\hline Elective & $131(71.2)$ \\
\hline Right colon & $56(30.3)$ \\
\hline Transvers colon & $9(4.9)$ \\
\hline Left colon & $31(16.8)$ \\
\hline Sigmoid colon & $44(23.8)$ \\
\hline Rectosigmoid & $44(23.8)$ \\
\hline Tumor size & \\
\hline Median & 4.7 \\
\hline Range & $2-13$ \\
\hline $\mathrm{T}$ & \\
\hline T1 & $10(5.4)$ \\
\hline T2 & 19 (10.3) \\
\hline T3 & $111(60.3)$ \\
\hline T4 & 44 (23.9) \\
\hline$N$ & \\
\hline NO & $112(60.8)$ \\
\hline N1 & $55(29.8)$ \\
\hline N2 & $17(9.2)$ \\
\hline
\end{tabular}

TNM

\begin{tabular}{ll} 
Stage 1 & $24(13.0)$ \\
Stage 2 & $87(47.3)$ \\
Stage 3 & $73(39.7)$ \\
\hline
\end{tabular}

\section{Results}

A total of 470 diagnosed CRC patients were operated between January 2014 and December 2018. After exclusions, 184 TNM stage 1-3 colon cancer patients who had curative surgery, were included in the study (Figure 1).

The patients and neoplasm demographics were listed in Table 1. T3 + T4 tumours (155\184) were $84.2 \%$ of the population and $39.1 \%(\mathrm{~N} 1+\mathrm{N} 2 ; 72 / 184)$ of cases had LN involvement (Table 1). 
Table 2. Distribution of patients according to histopathological and radiological findings

\begin{tabular}{|c|c|c|c|c|}
\hline & & histopathological ly & node involvement & \\
\hline & & $\mathrm{pLN}+$ & pLN- & \\
\hline preoperative CT & $\mathrm{rLN}+$ & True positive(n): 42 & False positive(n):22 & $\mathrm{PPV}^{*}: 65.6 \%$ \\
\hline images & rLN- & $\begin{array}{c}\text { False negative }(n): 30 \\
\text { Sensitivity: } 58.3 \%\end{array}$ & $\begin{array}{l}\text { True negative(n):90 } \\
\text { Spesificity: } 80.3 \%\end{array}$ & $\mathrm{NPV}^{* *}: 75.0 \%$ \\
\hline
\end{tabular}

Table 3. PPV, NPV, Sensitivity, Specificity, and Accuracy

\begin{tabular}{cccccc}
\hline & PPV $^{*}$ & NPV $^{* *}$ & Sensitivity & Specificity & Accuracy \\
\hline $\begin{array}{c}\text { Total } \\
(\mathrm{n}: 184)\end{array}$ & $65.6 \%$ & $75.0 \%$ & $58.3 \%$ & $80.3 \%$ & $71.7 \%$ \\
\hline $\begin{array}{c}\mathrm{T} 1+\mathrm{T} 2 \\
(\mathrm{n}: 29)\end{array}$ & $25.0 \%$ & $84.0 \%$ & $20.0 \%$ & $87.5 \%$ & $75.8 \%$ \\
\hline $\begin{array}{c}\text { T3+T4 } \\
(\mathrm{n}: 155)\end{array}$ & $68.3 \%$ & $72.6 \%$ & $61.1 \%$ & $78.4 \%$ & $70.9 \%$ \\
\hline $\begin{array}{c}\text { Elective Surgery } \\
(\mathrm{n}: 131)\end{array}$ & $67.3 \%$ & $70.7 \%$ & $57.8 \%$ & $78.3 \%$ & $69.4 \%$ \\
\hline $\begin{array}{c}\text { Emergency Surgery } \\
(\mathrm{n}: 53)\end{array}$ & $60.0 \%$ & $84.2 \%$ & $60.0 \%$ & $84.2 \%$ & $77.3 \%$ \\
\hline $\begin{array}{c}\text { Right+Transvers Colon } \\
(\mathrm{n}: 65)\end{array}$ & $63.3 \%$ & $80.0 \%$ & $73.0 \%$ & $71.7 \%$ & $72.3 \%$ \\
\hline $\begin{array}{c}\text { Left+Sigmoid+Rectosigmoid } \\
\text { Colon (n:119) }\end{array}$ & $67.6 \%$ & $72.9 \%$ & $50.0 \%$ & $84.9 \%$ & $71.4 \%$ \\
\hline "positive predictive value, ${ }^{* *}$ negative predictive value & & &
\end{tabular}

A comparison of preoperative CT images with histopathological findings revealed true positive and negative, false positive and negative cases (Table 2). We found 42 true positives, 90 true negatives, 22 false positives, and 30 false negatives.

Diagnosis of malign LN's PPV, NPV, sensitivity, specificity and accuracy rates were; $65.6 \%$ (95\% CI 55.5\%- 74.4\%), $75 \%$ (95\% CI 69.22\%-80\%), $58.3 \% \quad(95 \%$ CI $46.11 \%-69.8 \%), 80.3 \% \quad(95 \%$ CI $71.7 \%-$ $87.2 \%$ ) and $71.7 \%$ (95\% CI $64.6 \%-78.1 \%$ ), respectively (Table 3 ).

\section{Discussion}

To date, there has been a tendency on multimodal therapies, including chemotherapy, radiotherapy, and surgical procedures to surgery alone therapies for different colon tumor stages [7]. One of the conspicous alteration of these treatment modalities is the NAC for local advanced and LN involved colon neoplasms, which gains significantly increased survival rates [8]. NAC has become the gold standard treatment modality for the esophagus, stomach, rectum, and breast cancer; however, it has been arguable validity for colon cancer.

CT is widely used to evaluate the primary tumoral lesions and distant metastasis for preoperative staging, in addition LN metastasis could be diagnosed accurately by CT preoperatively. The previous studies stated that; the sensitivity of CT for T3 and T4 tumors was above $90 \%$ in the evaluation of pathological $\mathrm{T}$ [9], while the sensitivity for 
detection of malignant $\mathrm{LN}$ ranged between $13 \%$ to $92 \%$ [10-12].

CT axial sliced images vary from $5 \mathrm{~mm}-8 \mathrm{~mm}$ to $10 \mathrm{~mm}$ in different studies; thus, limitations and discussions in evaluating $\mathrm{LN}$ with $\mathrm{CT}$ are associated with these variable and wideranged results. Dighe et al. stated that results were better in determining the metastatic LN when the axial sliced was $\leq 5 \mathrm{~mm}$ with their metanalysis study [13].

The definition of metastatic LN's image on CT is variable in different studies. LN's diameter size $>5 \mathrm{~mm}$ [14], size $>8 \mathrm{~mm}$ [15], size $>1 \mathrm{~cm}$ [16], $\geq 3$ number of LN [16], and large LN with irregular contours [14] were defined as metastatic LN in some studies. However, inflammatory large-sized LN, metastatic small-sized, and non-clustering LN have revealed that it is misleading to use dimensional or morphological findings alone in the evaluation of metastatic LN [17].

Therefore, researchers have began to conduct studies using more than one findings in the evaluation of metastatic LN. Rolven et al. reported that the CT sensitivity was $85 \%$, and specificity was $75 \%$ in detecting stage 3 colon cancer, using together with the internal heterogeneity and irregular LN border [18]. In another study where LN size $>5 \mathrm{~mm}$ and $\backslash$ r irregular contours defined as metastatic LN, CT sensitivity and specificity were $64 \%$ and $53 \%$, respectively [19].

Measuring the axial length of $\mathrm{LN}$ is another commonly used method for LN evaluation; however, an $\mathrm{LN}$ shorter than $1 \mathrm{~cm}$ in axial sequence may be longer than $1 \mathrm{~cm}$ in sagittal or coronal sequences. Kanamoto et al. suggested two or three-dimensional reconstruction methods to increase sensitivity, specificity, and accuracy rates in their studies [20], but these methods seems to be timeconsuming. They also stated that in axial sequence, CT images using shortllong axis ratio $\geq 0.8$ to define metastatic $\mathrm{LN}$ raised sensitivity to $87 \%$ and specificity to $80 \%$ [20].

The low rate of intraabdominal adipose tissue complicates to distinguish the infiltrated tumor into the pericolonic adipose tissue from local LN metastasis, and it is accepted that evaluation of LN status with CT will be difficult for these patients. Acute obstructive colon neoplasms with over dilated colon segments will distort the CT images, leading LN evaluation. On the other hand, Sjovall et al. reported that there was no difference between CT evaluation of primary colon tumor and histopathological $\mathrm{T}$ and $\mathrm{N}$ depending on criterias such as age, gender, BMI, emergency surgery, and localization of the tumor [21]. We used only intravenous contrast for emergency surgery and both intravenous and oral contrast for elective surgery patients during CT. We also observed that there was no significant proportional difference in terms of lymph node evaluation between patients who underwent emergency and elective surgery. Likewise, there was no abnormal change according to the tumor location according to current study. According to our radiologic criteria, the assessment of LN status with CT resulted in a moderate sensitivity and specificity for both elective and emergent patients.

Preoperative CT has not been able to get desired results in the evaluation of LN. Once we defined the metastatic $\mathrm{LN}$ as diameter $>1$ $\mathrm{cm}$ andlor $\geq 3$ clustered LN, $11.9 \%$ (22/184) patients would get unnecessary NAC and $16.3 \%(30 / 184)$ patients who were a candidate for NAC would not get NAC in our study. The $\mathrm{T} 1+\mathrm{T} 2$ subgroup analysis revealed that; PPV and sensitivity were significantly lower than the other groups. These results indicated that; it is necessary to determine the structural findings as well as the dimensional findings, even $\mathrm{T}$ status, and all findings together in determining the metastatic LN. Besides, 
radiologic criteria for lymph node metastases on $\mathrm{CT}$ in colon cancer resulted in moderate specificity and sensitivity both in left sided and right sided disease.

The retrospective nature of the study, single radiologist examination, and the limited number of patients are the limitation of our study.

In conclusion, although $\mathrm{CT}$ has been performed via thinner axial sliced images and relatively more homogeneous groups compared to literature, the results we obtained in the evaluation of patients with colon cancer with preoperative CT are not satisfactory. In order to reach an improvement in universal definition and accuracy for the different treatment options, there is a need for further studies with a prospective, more significant number of patient groups, using thin axial sliced and three-dimensional reconstruction methods and examining more than one findings for colon cancer patients' preoperative LN examination with CT.

\section{REFERENCES}

1) O'Connell MJ, Colangelo LH, Beart RW, Petrelli NJ, Allegra CJ, Sharif S, et al. Capecitabine and oxaliplatin in the preoperative multimodality treatment of rectal cancer: surgical end points from National Surgical Adjuvant Breast and Bowel Project trial R-04. J Clin Oncol 2014; 32: 19271934.

2) National Comprehensive Cancer Network. NCCN Clinical Practice Guidelines in Oncology. Colon Cancer. Version 3, 2013.

3) Dighe S, Swift I, Magill L, Handley K, Gray $R$, Quirke $P$, et al. Accuracy of radiological staging in identifying high-risk colon cancer patients suitable for neoadjuvant chemotherapy: a multicentre experience. Color Dis Off J Assoc Coloproctol G B Irel 2012; 14(4):438-444.

4) Choi $A H$, Nelson RA, Schoellhammer HF, Cho $W$, Ko $M$, Arrington $A$, et al. Accuracy of computed tomography in nodal staging of colon cancer patients. World J Gastrointest Surg. 2015; 7(7): 116-122.

5) Kwak JY, Kim JS, Kim HJ, Ha HK, Yu CS, Kim JC. Diagnostic value of FDG-PET/CT for lymph node metastasis of colorectal cancer. World J Surg 2012; 36: 1898-1905.

6) Jessup JM, Goldberg RM, Asare EA, Benson III A, Brierley J, Chang G,et al. AJCC cancer staging manual. 8th edition. New York: SpringerVerlag; 2017. p. 251-274.

7) Wiegering $A$, Isbert $C$, Dietz UA, Kunzmann $V$, Ackermann $S$, Kerscher $A$, et al. Multimodal therapy in treatment of rectal cancer is associated with improved survival and reduced local recurrence-a retrospective analysis over two decades. BMC Cancer 2014; 14:816.

8) De Caluwe L, Van Nieuwenhove $Y$, Ceelen WP. Preoperative chemoradiation versus radiation alone for stage II and III resectable rectal cancer. Cochrane Database Syst Rev 2: 2013; CD006041.

9) Wiegering $A$, Kunz $M$, Hussein M, Klein I, Wiegering $\mathrm{V}$, Uthe $\mathrm{FW}$, et al Diagnostic value of preoperative CT scan to stratify colon cancer for neoadjuvant therapy. Int J Colorectal Dis. 2015; 30(8): 1067-1073.

10) Chamadol $N$, Ninpiethoon $T$, Bhudhisawasd $V$, Pairojkul $C$. The role of $C T$ scan in preoperative staging of colorectal carcinoma. J Med Assoc Thai 2005; 88: 1847-1853.

11) Filippone $A$, Ambrosini $R$, Fuschi $M$, Marinelli T, Genovesi D, Bonomo L. Preoperative $\mathrm{T}$ and $\mathrm{N}$ staging of colorectal cancer: accuracy of contrast-enhanced multi-detector row CT colonography e initial experience. Radiology 2004; 231: 83-90.

12) Nerad E, Lahaye MJ, Maas $M$, Nelemans P, Bakers FC, Beets GL, et al. Diagnostic Accuracy of CT for Local Staging of Colon Cancer: A 
Systematic Review and Meta-Analysis. AJR Am J Roentgenol. 2016; 207(5): 984-995.

13) Dighe $S$, Purkayastha $S$, Swift I, Tekkis PP, Darzi A, $A^{\prime}$ Hern $R$, et al. Diagnostic precision of CT in local staging of colon cancers: a meta-analysis. Clin Radiol 2010; 65:708-719.

14) Dighe $S$, Blake $H$, Koh MD, Swift I, Arnaout A, Temple L, et al. Accuracy of multidetector computed tomography in identifying poor prognostic factors in colonic cancer. Br J Surg 2010; 97: 1407-1415.

15) Chi Y, Zhang $X$, Li J, Sun $Y$. To be or not to be: significance of lymph nodes on pretreatment CT in predicting survival of rectal cancer patients. Eur J Radiol 2011; 77: 473-477.

16) Smith $N$, Bees $N$, Barnachano $Y$, Norman A, Swift R, Brown G. Preoperative computed tomography staging of nonmetastatic colon cancer predicts outcome: implications for clinical trials. Br J Cancer 2007; 96: 1030-1036.

17) de Vries FE, da Costa DW, van der Mooren $K$, van Dorp TA, Vrouenraets BC. The value of preoperative computed tomography scanning for the assessment of lymph node status in patients with colon cancer. Eur J Surg Oncol. 2014; 40(12): 1777-1781.
18) Rollvén E, Blomqvist L, Öistämö E, Hjern F, Csanaky G, Abraham-Nordling M. Morphological predictors for lymph node metastases on computed tomography in colon cancer. Abdom Radiol (NY). 2019; 44(5): 17121721.

19) Dighe S, Swift I, Magill L, Handley K, Gray $R$, Quirke $P$, et al. Accuracy of radiological staging in identifying high-risk colon cancer patients suitable for neoadjuvant chemotherapy: a multicentre experience. Colorectal Dis. 2012; 14: 438-444.

20) Kanamoto $T$, Matsuki M, Okuda J, Inada $Y$, Tatsugami $\mathrm{F}$, Tanikake $\mathrm{M}$, et al. Preoperative evaluation of local invasion and metastatic lymph nodes of colorectal cancer and mesenteric vascular variations using multidetector-row computed tomography before laparoscopic surgery. J Comput Assist Tomogr 2007; 31: 831839.

21) Sjövall A, Blomqvist $L$, Egenvall $M$, Johansson $H$, Martling A. Accuracy of preoperative $\mathrm{T}$ and $\mathrm{N}$ staging in colon cancer--a national population-based study. Colorectal Dis. 2016; 18(1): 73-9.

Corresponding author e-mail: mtanerbostanci@gmail.com

Orcid ID:

Mustafa Taner Bostancı 0000-0003-2876-2683

Ibrahim Yılmaz 0000-0003-0759-0974

Yeliz Aktürk 0000-0002-0244-0478

Aysun Gökçe 0000-0002-4026-6503

Mehmet Saydam 0000-0003-0953-4589

Işıl Esen Bostancı 0000-0003-4090-5050

Doi: $10.5505 /$ aot.2021.37790 